\section{Rethinking sex and the selfish gene: why we do it}

\author{
Sex, Speciation and Selfishness \\ Niles Eldredge \\ W.W. Norton E Company, New York, NY, USA; 2004. 269pp. \\ $£ 18.99$, hardback. ISBN 0393050823.
}

Heredity (2006) 96, 271-272. doi:10.1038/sj.hdy.6800798

\section{Reviewed by M Midgley}

Ever since the launch of sociobiology some 30 years back, questions such as the one in Niles Eldredge's title (why humans have sex) have been mired in disastrous ambiguity. Officially, these are just questions about evolutionary function, like 'why have elephants got trunks?'. But it has proved quite impossible to isolate them from much more exciting and familiar queries about individual motive, questions such as, 'why did Booth kill Lincoln?'.

This confusion already pervaded the early sociobiological manifestoes. Both EO Wilson and Richard Dawkins constantly mixed lively slogans about motivation with their technical arguments about evolutionary genetics - as, for instance, when Dawkins declared that we cannot possibly have any natural generous or altruistic motives because 'we are born selfish' (Selfish Gene $\mathrm{p} 3$ ). At the everyday level, this campaign piled yet further wild psychological and political ideas on the foundations that had already been laid by the 19thcentury Social Darwinists. For at that time, as Eldredge rightly says -

As a rationale for the often ruthless tactics of Victorian capitalism on up through today's big business, the rationalizing of the competitive devil-take-the-hindmost human behaviour in the name of Darwinian biology probably did more for the social acceptance of the idea of evolution than did the revelation - repugnant to so many - that all life, including our own, is descended from a common ancestor.

Officially, Sociobiology was designed to correct that error by turning 'selfishness' into a metaphor and removing it from the individual to the genetic level. But, because of these foundational confusions, it has instead merely persuaded the public that selfishness (of the quite ordinary, literal kind) is the only possible pattern at both levels. It also adds, for anyone who doesn't like this, a fatalistic assurance that we can do nothing about it anyway since we are only helpless vehicles of our genes - 'lumbering robots' (SG p 21).

To cure this widespread confusion, Eldredge has deliberately written his attack on the concept in strong, clear, everyday language. His central target is the inflation of genes into independent, ultimate causes 'drivers' of evolution, much as a human driver drives a car - rather than merely ordinary factors in the causal process. He argues that the fossil records do not support this inflation. Speciation events - which are rare - have mostly not resulted from continuous competition among genes but from outside disturbances, usually climatic ones. Genes, then, are 'passive recorders of what worked better than what'. 'Genes don't drive evolution; the environment does. But genes do supply the raw materials from which life evolved anew. There is a yin and yang here; not a one-way street'. 'There is no active evolutionary process per $s e^{\prime}$. He notes how the personifying metaphor of 'selfishness' supports the misleading story of gene spontaneity - 'a rhetorical ploy to make genes seem like active players'. Indeed it is surely remarkable how readily, in this context, biologists have accepted the imagery of genes as independent causal agents, something which they tend to resist strongly in discussions of human free-will.

The question about the evolutionary function of sex poses well-known difficulties for the idea that evolution is a race between individuals competing to maximise their gene spread, since dividing the work of reproduction halves each partner's share. Eldredge considers the various devices that have been proposed to protect the gene-centred approach from this drawback, but opts, himself, for a quite different solution, one centring on the crucial function of species in evolution. Species formation, he says, is necessary to provide organisms with the rich and varied repertoires of characteristics that are needed to shape the more complex forms of life. That complexity requires a sizable reproductive group of individuals who vary adequately but within certain fixed limits. For this, genes must be shared around, and when that is successfully done the results often prove enduring. 'Species resist extinction, often lasting for millions of years... asexual clones do not have such staying power, and that is probably the real reason why, in most organisms, sexual reproduction is more common than asexual reproduction'.

This nongene-centred approach naturally also has consequences for the other question - the one about the place of sexual motivation in human life. Here, as Eldredge points out, it is very strange to suggest that reproductive ambition in some sense underlies and determines this and all other motives. Most of the time, after all, other ends are being pursued

\footnotetext{
Life is not 'about' evolving. Life is about living.... Even Casanova had to eat... Though sex plays a greater role in the average human life than in the lives of almost all other creatures, ... our lives are much more about economics than about sex ... Indeed it is because so much of human sex is about economics, about making a living, that we spend so much more time than lions or armadillos do in all manner of sexual indulgences.
}

Here, I think, Eldredge is making a sound point in rather paradoxical terms, extending the use of the word 'economics' somewhat. The sound point is that human motivation - including sexual motivation - is not a simple one-way force but a complex approach to life, shaped by the endless social and psychological factors that give meaning to particular choices. For that reason, sexual acts can indeed often flow from nonsexual motives. He works with this simple 
antithesis between reproductive and economic aims throughout the book, running together the general necessity for 'making a living' with the much more interesting point that we can only choose activities which appeal to us as ends in themselves. But he knows that 'living' is indeed something much wider than 'making a living'. Motives are not simple gadgets invented by a gene-obsessed Providence but complex tastes dispositions which have somehow arisen in a species and can survive provided that they are not unworkably disastrous.

Altogether, however, this is a splendid book - rich, clear, astute and sensible, a badly needed spring-cleaning of very influential errors.

M Midgley

1A Collingwood Terrace, Newcastle on Tyne, NE2 2JP, UK E-mail:mbm@coll1a.demon.co.uk 